\title{
Lactate Dehydrogenase as Predictor for Severity in Sickle Cell Disease
}

\section{A. Ehtesham ${ }^{1}$, Bhavana Lakhkar², Rakesh Adkane ${ }^{3}$}

Section: Healthcare

Sci. Journal Impact

Factor: 6.1 (2018)

ICV: 90.90 (2018)

(c) (3) (8)

Copyright@IJCRR

\author{
'Resident, Department of Paediatrics, Datta Meghe lnstitute of Medical Sciences, Sawangi, Wardha, India; ${ }^{2}$ Professor and Head Department \\ of Paediatrics, Datta Meghe Institute of Medical Sciences, Sawangi, Wardha, India; ${ }^{P}$ Professor, Mechanical Engineering, Yeshwantrao Chavan \\ College of Engineering, Nagpur, India.
}

\section{ABSTRACT}

Introduction: Pyruvate to lactate in a glycolytic pathway is caused by enzyme lactate dehydrogenase (LDH) with the conversion of NADH TO NAD+. Lactate dehydrogenase can be found in different body tissues. For hemolysis marker lactate dehydrogenase levels can be used. In sickle cell anaemia patient those who are in the steady-state (SS) there will be an increase in the level of lactate dehydrogenase(LDH). In sickle cell disease, the life of the patient is hampered due to crisis and it is very difficult to predict the crisis. Hence in our study, we used a marker lactate dehydrogenase (LDH ) to predict the severity of the crisis.

Objectives: To study the ability of serum LDH levels in predicting the severity of disease in sickle cell anaemia.

Methodology: To achieve the objective we assess serum LDH levels during steady-state and crisis and to correlate above with chronic complications ( $\mathrm{PH}$, Microalbuminuria, Liver functions) and severity of the crisis.Patients fulfilling selection criteria will be recruited after obtaining written consent. Detailed history including the age of onset, frequency and severity of the crisis, frequency of admissions and transfusions, quality of follow up, quality of treatment received will be taken. Detailed examination including anthropometry will be recorded. The severity of the acute crisis will be decided based on the duration of pain more than 2 days, need for admission \& stay more than 3 days, death, need for surgery, need for support and need for other procedure.

Expected Results: We expect the LDH level to be significantly higher during the crisis. If steady-state patients are considered LDH level will be high in patients with moderate and severe disease (frequency more than 3/ year).

Key Words: Lactate Dehydrogenase, Sickle Cell Disease, Prediction

\section{INTRODUCTION}

Pyruvate to lactate in a glycolytic pathway is caused by enzyme lactate dehydrogenase (LDH) along with the conversion of nicotinamide adenine dinucleotide to nicotinamide adenine dinucleotide + . Lactate dehydrogenase can be found in all the body tissues. Lactate dehydrogenase is found in five different isoenzymes types $1-5$ as by their electrophoretic motility. ${ }^{1}$ Their distribution of all the types of $\mathrm{LDH}$ is different across different body tissues. 1, 2 can be found in $\mathrm{RBC}$ and heart smooth muscle; type 3 is found to be highest in lungs; type 4 is found to be highest in the kidney, placenta, pancreas; and type 5 is found in increased levels in skeletal muscle and liver. ${ }^{2}$ The serum LDH routine evaluation includes all of the 5 types.

Along with increase reticulocyte count, increase in indirect bilirubin level, and decrease in serum haptoglobin,
Lactate dehydrogenase (LDH) also has been used as a marker of hemolysis. In sickle cell anaemia in the steadystate (SS) there will be an increase in the level of lactate dehydrogenase $(\mathrm{LDH}) .^{3}$ And when painful vasoocclusive crises (VOCs) like dactylitis, sickle cell hepatopathy and abdominal crisis, and acute chest syndrome, the lactate dehydrogenase levels may further increase in some sickle cell patients due to increase in hemolysis ${ }^{4}$. In one study Neely et al found that increase in serum LDH was not correlated with plasma $\mathrm{Hb}$ level, indicating that the source of LDH is not secondary to hemolysis but rather to tissue damage. ${ }^{1}$

In a forthcoming enlightening partner concentrate in youngsters between a half year to 18 years indicated that the LDH chemical level increments fundamentally during an emergency contrasted and consistent state esteems and that there is a critical positive relationship between's LDH levels and the seriousness of pain. ${ }^{5}$ however, raised LDH levels during

\section{Corresponding Author:}

Dr. M. A. Ehtesham, Department of Paediatrics, Datta Meghe Institute of Medical Sciences, Sawangi, Wardha, India.

Contact: 7013562560; Email: drehty@gmail.com

ISSN: 2231-2196 (Print)

Received: 20.08 .2020
ISSN: 0975-5241 (Online)

Revised: 15.09 .2020
Accepted: 25.10 .2020 
the hour of affirmation confirmation for VOC was related with the extreme result, including, passing and exacerbating clinical state expecting the move to the emergency unit, the patients with sickle cell sickness (SCD). ${ }^{6}$

The predominance of microalbuminuria and proteinuria in the patients considered was $5 \%$ and $15 \%$, separately. Univariate and multivariate investigations demonstrated a critical connection between LDH level, microalbuminuria, increment in unconjugated bilirubin levels and proteinuria. ${ }^{7}$ In an examination by Kato et al announced a relationship among hemolysis and subphenotypes of Sickle cell malady, including pneumonic hypertension $(\mathrm{PH})$, yet the conclusion of hemolysis depended on Lactate dehydrogenase levels. ${ }^{8}$ In an examination by Autauga et al revealed a noteworthy connection between Pulmonary hypertension and microalbuminuria, yet no connection with hemolysis. ${ }^{9}$

This information proposes that it is the LDH level that is no doubt connected with $\mathrm{PH}$ and microalbuminuria regardless of the seriousness of hemolysis. In any case, except if the relationship among hemolysis and $\mathrm{PH}$ and different inconveniences of SCD is demonstrated by RBC endurance considers, this remaining parts speculation. Raised degrees of serum LDH is a marker of vague tissue harm. The clinical picture and the degree of LDH isoenzymes may give pieces of information to its source ${ }^{10}$. The results will be analysed with SPSS.

\section{MATERIALS AND METHODS}

Patients fulfilling selection criteria will be recruited after obtaining written consent. Detailed history including the age of onset, frequency and severity of the crisis, frequency of admissions and transfusions, quality of follow up, quality of treatment received will be taken. Detailed examination including anthropometry will be recorded. The information will be entered in a prevalidated pre-tested proforma.

Following investigations will be carried out

- Complete blood cell profile ( $\mathrm{Hb} \%$, Total Leukocyte Count (TLC), Differential Leukocyte Count (DLC)

- Serum LDH levels

- Microalbuminuria, ECHO for pulmonary hypertension, SGPT, SGOT.

- Other investigations will be done as required.

Chronic disease will be called severe if any 1 of the major organ affected like kidney, heart or liver based on investigations (microalbuminuria, echo for pulmonary hypertension, SGPT, SGOT, serum bilirubin) and number of crisis in a year.

The severity of the acute crisis will be decided based on duration of pain more than 2 days, need for admission and stay more than 3 days, death, need for surgery, need for support and need for other procedure.

\section{Study design}

This is Prospective Cohort Study decided to carry at Acharya Vinoba Bhave Rural Hospital, Sawangi, Maharashtra, Located in Central India. Participants will be grouped as GROUP A which are diagnosed patients of sickle cell anaemia in steady-state for at least 6 weeks and GROUP B which are patients presenting with the acute crisis.

\section{Inclusion criteria}

Patients between 6 months to 18 years diagnosed to have sickle cell disease either in steady-state or crisis.

\section{Exclusion criteria}

Patients denying consent

\section{Variables \\ - $\mathrm{Hb} \%, \mathrm{TLC}, \mathrm{DLC}, \mathrm{PS}-\mathrm{CBC}$ \\ - Serum LDH levels \\ - Microalbuminuria, echo for pulmonary hypertension, SGPT, SGOT, SR. Creatinine}

\section{Study size:}

The estimated sample size for one-sample comparison of proportion to the hypothesized value

Test Ho: $p=0.4200$, where $p$ is the proportion in the population

\section{Assumptions}

Alpha $=0.0500$ (two-sided)

Power $=0.9000$

Alternative $\mathrm{p}=0.2500$

\section{Estimated required sample size (n): 81}

\section{Quantitative variables: $\mathrm{LDH}$}

\section{Expected Outcomes/Results:}

1) We expect the LDH level to be significantly higher during the crisis.

2) If steady-state patients are considered the $\mathrm{LDH}$ level will be high in patients with moderate and severe disease. (frequency more than 3 / year)

3) During crisis LDH levels will be high in severe crisis requiring transfusions, prolong stay or any other intervention.

\section{DISCUSSION}

Serum LDH is typically raised in sickle cell frailty in the consistent state (SS). During excruciating vasoocclusive emergencies (VOCs), the LDH may increment further in certain patients as a result of hyperhaemolysis, as appeared by RBC endurance considers. Information proposes that expansion in LDH level is in all likelihood connected with an expanded 
number of emergency. Raised degrees of serum LDH is a marker of vague tissue harm. In this way serum, LDH levels are raised during an emergency. An imminent engaging partner concentrate in kids indicated that the LDH level increments fundamentally during VOCs contrasted and consistent state esteems and that there is a noteworthy positive connection between LDH levels and the seriousness of torment however not among LDH and $\mathrm{Hb}$. Also, raised LDH levels at confirmation for VOCs were related to extreme result, including passing and declining clinical state expecting the move to the emergency unit, grown-up patients with sickle cell infection (SCD). Raised degrees of serum LDH is a marker of vague tissue harm. The clinical picture and the degree of $\mathrm{LDH}$ isoenzymes may give intimations to its source. Various articles in the neighbourhood setting identified with this examination were reviewed. Wasnik et al conducted an evaluation of serum zinc and antioxidant vitamins in adolescent homozygous sickle cell patients in Wardha. ${ }^{11}$ Baliga et al studied malondialdehyde levels in serum and saliva of children affected with sickle cell anemia. ${ }^{12}$ Similar child health-related studies were reported. ${ }^{13-17}$ Jaiswal et al reported a comparative study on peripapillary retinal nerve fibre layer thickness in patients with iron-deficiency anemia. ${ }^{18}$

\section{CONCLUSION}

Lactate Dehydrogenase level will be a useful diagnostic criterion for sickle cell disease cases.

\section{ACKNOWLEDGMENT}

Authors acknowledge the immense help received from the scholars whose articles are cited and included in references to this manuscript. The authors are also grateful to authors / editors / publishers of all those articles, journals, and books from which the literature for this article has been reviewed and discussed.

Conflict of Interest: None

Funding: Self

\section{REFERENCES}

1. Ballas SK. Lactate dehydrogenase and hemolysis in sickle cell disease. Blood 2013 3;121(1):243-4.

2. Kato GJ, McGowan V, Machado RF, Little JA, Taylor J, Morris $\mathrm{CR}$, et al. Lactate dehydrogenase as a biomarker of hemolysis-associated nitric oxide resistance, priapism, leg ulceration, pulmonary hypertension, and death in patients with sickle cell disease. Blood. 2006;107(6):2279-85.

3. Neely CL, Wajima T, Kraus AP, Diggs LW, Barreras L. Lactic acid dehydrogenase activity and plasma haemoglobin elevations in sickle cell disease. Am J Clin Pathol 1969 1;52(2):167-9.
4. van Beers EJ, Schaap MC, Berckmans RJ, Nieuwland R, Sturk A, van Doormaal FF, et al. Circulating erythrocyte-derived microparticles are associated with coagulation activation in sickle cell disease. Haematologica. 2009;94(11):1513-9.

5. Nouraie M, Lee JS, Zhang Y, Kanias T, Zhao X, Xiong Z, et al. The relationship between the severity of hemolysis, clinical manifestations and risk of death in 415 patients with sickle cell anaemia in the US and Europe. Haematologica. 2013;98(3):46472 .

6. Ballas SK, Marcolina MJ. Hyperhemolysis during the evolution of uncomplicated acute painful episodes in patients with sickle cell anaemia. Transfusion 2006;46(1):105-10.

7. White JM, Muller MA, Billimoria F, Davis LR, Stroud CE. Serum $\alpha$-hydroxybutyrate Levels in Sickle-Cell Disease And Sickle-Cell Crisis. Lancet 1978;311(8063):532-3.

8. Tumblin A, Tailor A, Hoehn GT, Mack AK, Mendelsohn L, Freeman L, Xu X, Remaley AT, Munson PJ, Suffredini AF, Kato GJ. Apolipoprotein AI and serum amyloid A plasma levels are biomarkers of acute painful episodes in patients with sickle cell disease. Haematologica 2010;95(9):1467-72.

9. Stojanovic KS, Steichen O, Lefevre G, Bachmeyer C, Avellino V, Grateau G, et al. High lactate dehydrogenase levels at admission for painful vaso-occlusive crisis is associated with severe outcome in adult SCD patients. Clinical biochemistry. 2012;45(18):1578-82.

10. Wasnik RR, Akarte NR. Evaluation of Serum Zinc and Antioxidant Vitamins in Adolescent Homozygous Sickle Cell Patients in Wardha, District of Central India. J Clin Diagn Res 2017;11(8): BC01.

11. Baliga S, Chaudhary M, Bhat S, Bhansali P, Agrawal A, Gundawar S. Estimation of malondialdehyde levels in serum and saliva of children affected with sickle cell anaemia. J Indian Soc Pedodontics Preventive Dents 2018 ;36(1):43.

12. Mittal V, Jagzape T, Sachdeva P. Care Seeking Behaviour of Families for their Sick Infants and Factors Impeding to their Early Care Seeking in Rural Part of Central India. J Clin Diagn Res 2018;12(4).

13. Baliga S, Chaudhary M, Bhat SS, Bhatiya P, Thosar N, Bhansali P. Determination of toral antioxidant capacity of saliva in sickle cell anaemic patients-A cross-sectional study. J Indian Soc Pedodont Preventive Dentis 2017;35(1):14.

14. Jagzape A, Jagzape T, Deshpande V. Simple visual reaction time in sickle cell disease patients of pediatric age group. Nat J Physiol Pharmacy Pharmacol 2017;7(12):1368-70.

15. Khatib MN, Kirubakaran R, Gaidhane S, Shankar AH, Quazi Syed Z. Yoga for improving functional capacity, quality of life and cardiovascular outcomes in people with heart failure. Cochrane Database Syst Rev 2017;2017(7).

16. Uddin S, Mahmood H, Senarath U, Zahiruddin Q, Karn S, Rasheed S, et al. Analysis of stakeholders networks of infant and young child nutrition programmes in Sri Lanka, India, Nepal, Bangladesh and Pakistan. BMC Public Health 2017;17.

17. Puri S, Fernandez S, Puranik A, Anand D, Gaidhane A, Syed ZQ, Patel A, Uddin S, Thow AM. Policy content and stakeholder network analysis for infant and young child feeding in India. BMC Public Health 2017;17(2):461.

18. Jaiswal S, Banait S, Daigavane S. A Comparative Study on Peripapillary Retinal Nerve Fiber Layer Thickness in Patients with Iron-Deficiency Anemia to Normal Population. J Datta Meghe Inst Med Sci Uni 2018; 13(1) 9-11. 